اثر اكسين و سيتوكينين بر برخى ويزَى هاى مورفوفيزيولوزيكى كياهجه و جوانهزنى بذر استويا (Stevia rebaudiana Bertoni)

\author{
راضيه صارمى '، حشمت اميدى "r."، عبدالامير بستانى '، \\ ' دانشجوى كارشناسى ارشد علوم و تكنولوزى بذر دانشكده علوم كشاورزى، دانشعاه شاهد تهر ان

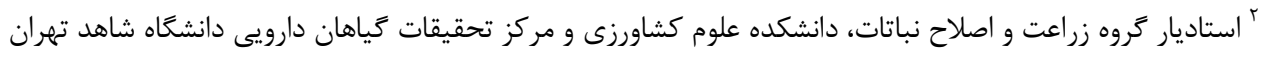

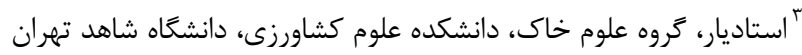

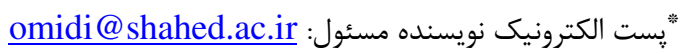

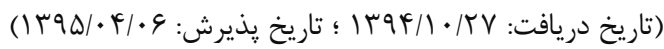

جكيده

اين تحقيق بهمنظور بررسى كارايى پيش تيشمار هورمونى در افزايش قدرت جوانهزنى و رشد اوليه گياهجه،

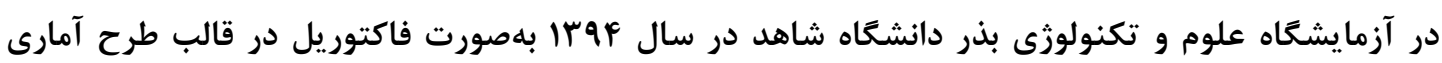

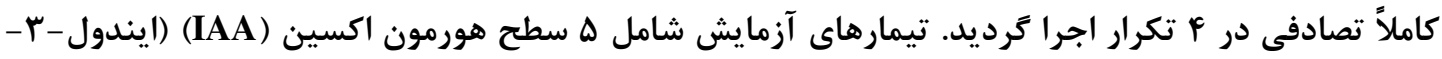

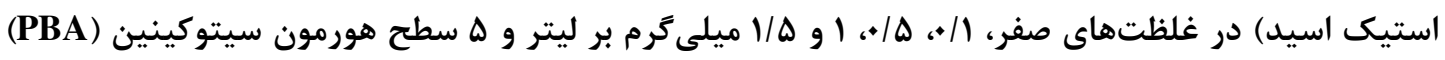

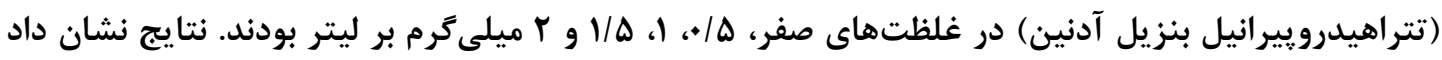

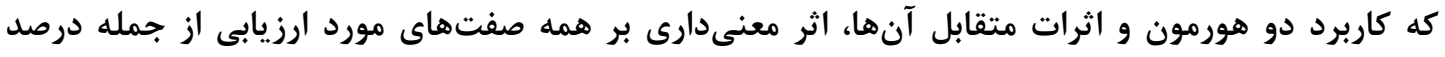

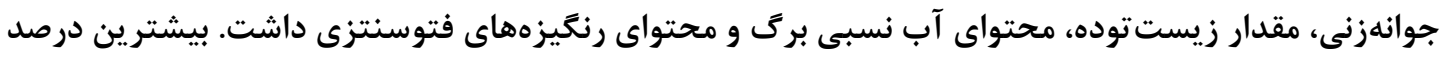

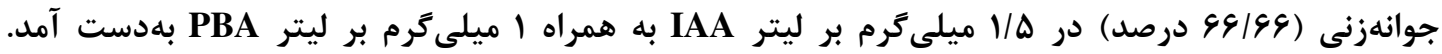

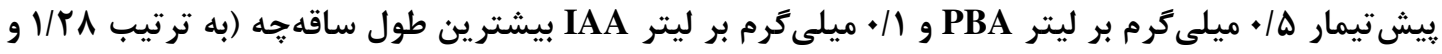

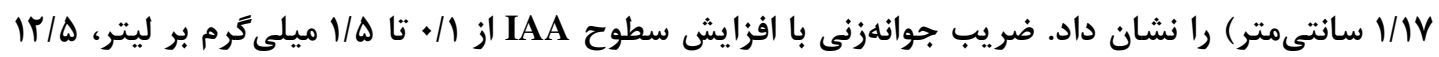

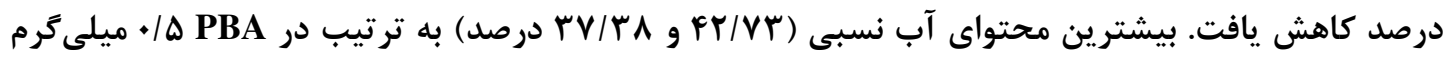

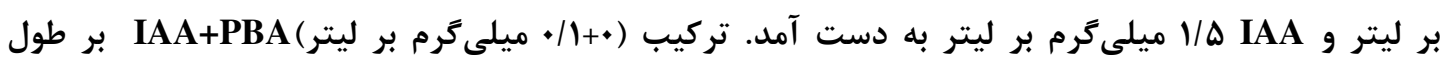

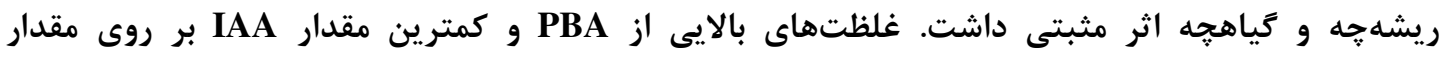

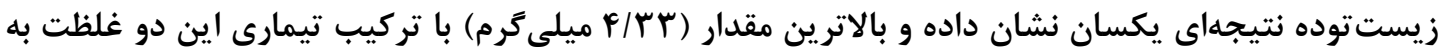

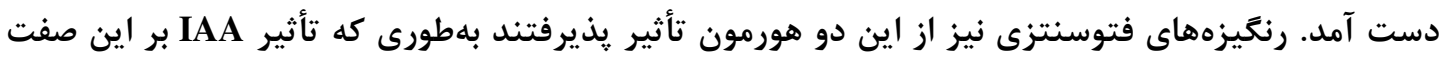

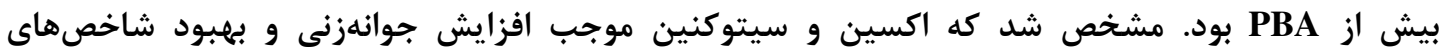

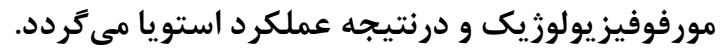

وازههاى كليدى: ايندول-r-استيك اسيد، تتراهيدروييرانيل بنزيل آدنين، ضريب جوانهزنى، زيست توده

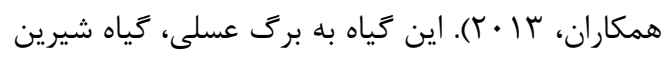

مقدمه

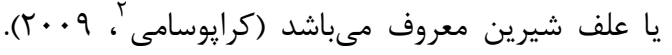

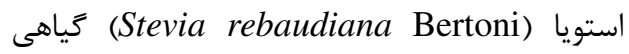

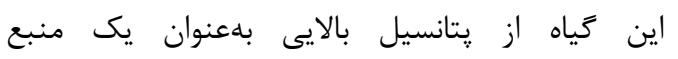
جندساله متعلق به خانواده آستراسه است (رينا' و

\footnotetext{
${ }^{2}$ Karuppusamy
}

${ }^{1}$ Raina 
ايندول ؟َ- استيك اسيد (IAA)، اكسين اصلى در

كياهان عالى است و اثرات عميقى در رشد و نمو كياه

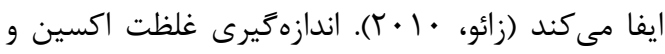

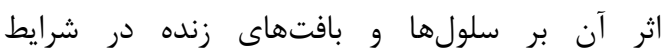

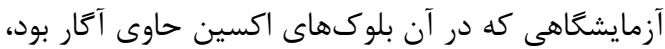
تحريك رشد بخش كولئويتيل جو دو سر را منجر شد و

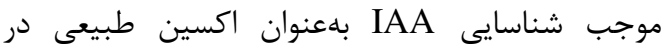

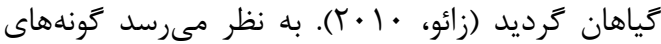

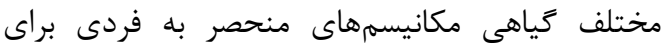

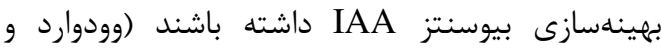

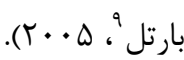

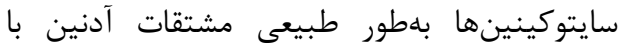

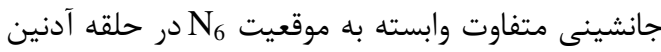

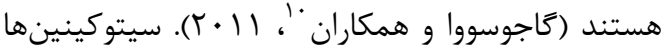

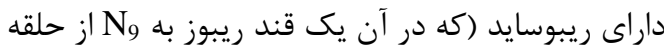

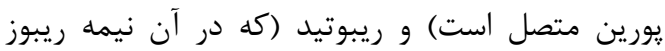

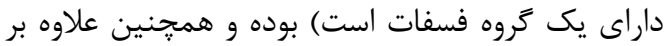

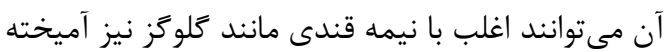

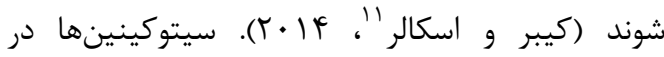
بسيارى از جنبههاى رشد و نمو كياه از جمله تقسيم سلولى، رشد ساقه، پِيرى برى، غالبيت انتهايى، روابط

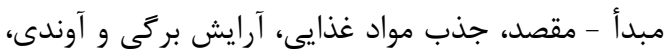

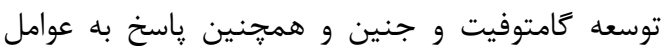
زنده و غيرزنده نقش دارند (كاجوسووا و همكاران،

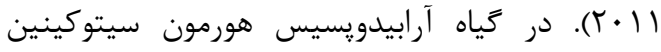
نقش مثبتى را در عملكرد مر يستم ساقه نشان داده است

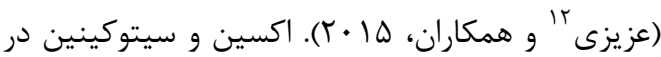

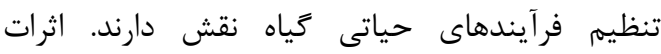
آنتاكونيستى و سينرزيستى اين دو هورمون بر همانيان سازماندهى، تشكيل و نكمهدارى مريستم را كنترل مى كند. سلولهاى مريستمى مى متوانند به بافتها و و اندامهاى جديد در محل يیشجنين تقسيم شوند. بلمطورى كه اندامهاى كياهى بالاى سطح زمين بلهوسيله مريستم انتهايى ساقه ايجاد مىشوند (عزيزى و همكاران،

${ }^{8}$ indole-3-acetic acid

${ }^{9}$ Woodward and Bartel

${ }^{10}$ Gajdosova

${ }^{11}$ Kieber and Schaller

${ }^{12}$ Azizi
شيرينكننده طبيعى برخوردار است كه تا •ها برابر شيرينتر از شكر است؛ اما در عين حال عملاً هيجّونها

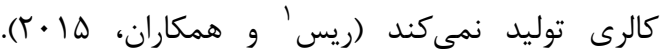
استويوسايد موجود در برك اين كياه بهعنوان جايكزينى بجاى ساكارز بكار مىرود و در درمان ديابت، جاقى و فشارخون مؤثر است و از يوسيدگى دنى دندان جلوكيرى

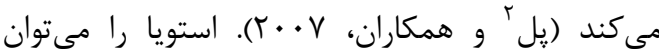
بهوسيله بذر تكثير كرد اما جوانهزنى آن ضعيف (بهطور

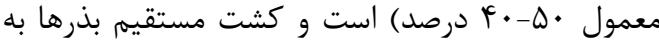
دليل اندازه كوجى آنها ممكن است منجر به شكست آند

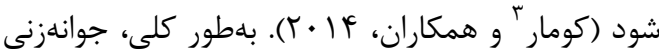
بذرها در اين گياه يك مشكل مهم است و بذرهايى كه

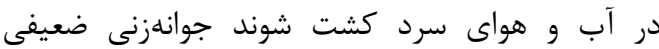

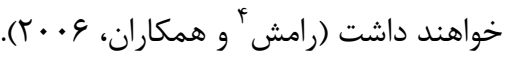

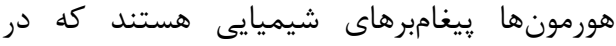
محل هاى هدف بر ميزان تنظيم و مقدار رشد سلولها در بافتهاى ريشه، ساقه، برك، جوانه، كل ها و ميوهها نقش

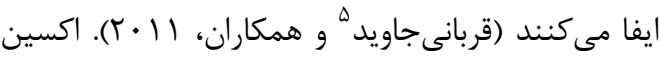

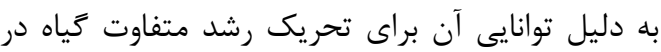
ياسخ به محرك كرانش يا نور بلعنوان يك هورمون رشد

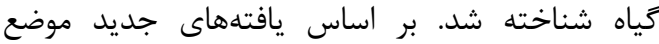
بيوسنتز اكسين نقش اساسى در بسيارى از فرايندهاى

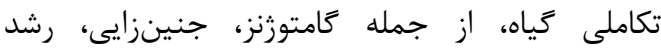
كياهجه، الكودهى آوندى و توسعه كَل ايفا مى كند (زائول،

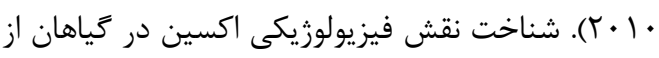
روى جكونگى קاسخ كياهان به اكسين خارجى صورت

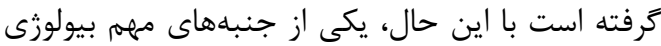
اكسين شناخت اختلالات رشد و نمو ناشى از كمبود إنائ اكسين است كه اين شناخت در صورتى كه درك آنى درستى از مسير بيوسنتز اكسين در دست نباشد اتفاق

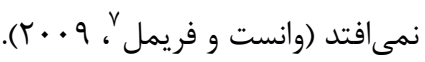

\footnotetext{
${ }^{1}$ Reis

${ }^{2} \mathrm{Pol}$

${ }^{3}$ Kumar

${ }^{4}$ Ramesh

${ }^{5}$ GhorbaniJavid

${ }^{6}$ Zhao

${ }^{7}$ Vanneste and Friml
} 
ميانگين طول ه گياهجه (بعد از f هفته) با استفاده از خط كش مدرج بر حسب سانتىمتر و وزنتر گياهجهها

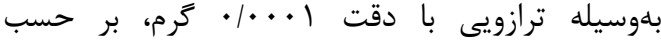
ميلى

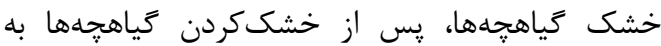

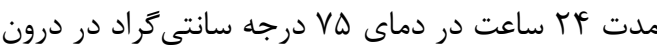
آون، از ترازوى دقيق استفاده شد.

براى محاسبه درصد جوانهزنى از رابطه ا كه توسط

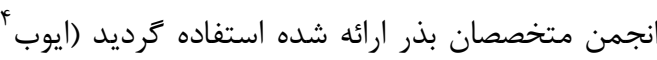

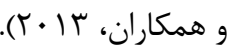
رابطه ا:

درصد جوانهزنى= (تعداد بذرهاى جوانهزدها تعداد

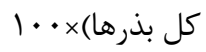

بلمنظور بررسى محتوى نسبى آب برگ، بافت تازه برگ را جدا كرده و يس از وزن نمودن برگ (وزن تر)

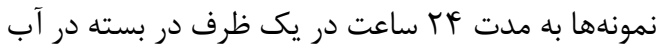

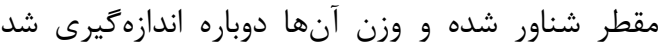

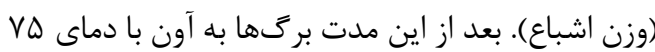

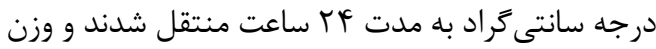

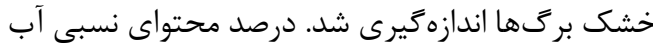

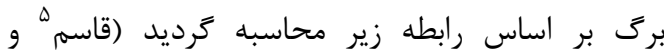

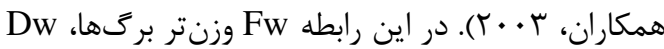

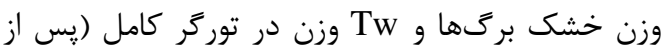
r r ساعت در آب مقطر) مى باشند.

$R W C=\left(\frac{F W-D W}{T W-D W}\right) \times 100$

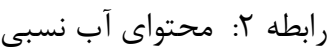
ضريب آلومترى با محاسبه نسبت وزنى ساقهجه به ريشهجه (باقرى و همكاران، • وץ|) و ضريب جوانهزنى طبق معادله زير محاسبه شد (فتحى امير خيز و

$$
\begin{aligned}
& \text { همكاران، (1) (1). } \\
& \text { رابطه سا: ضريب جوانهزنى }
\end{aligned}
$$

$G C=\left(\frac{1}{M G T}\right) \times 100$

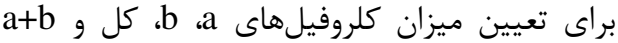
(در مرحله F Y ب بركى) بر حسب ميلى

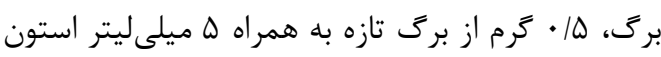

\section{${ }^{4}$ Ayub}

${ }^{5}$ Qasim
ها • (؟). اين تحقيق بلمنظور بررسى تأثير دو هورمون

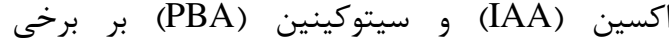
ويززگى هاى مورفولوزيكى، خصوصيات جوانهزنى، محتواى كلروفيل و رطوبت نسبى برگ گياه دارويى استويا انجام

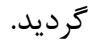

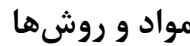

بلمنظور بررسى واكنش گياه دارويى استويا به منابع هورمونى در مراحل اوليه جوانهزنى مطالعهاى در سطوح مختلف هورمونى بهصورت فاكتوريل بر پايه طرح كاملاً

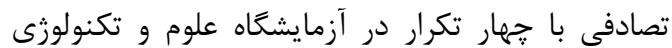

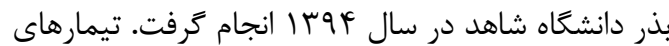

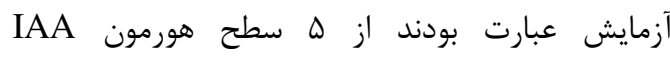

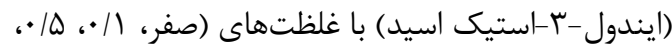
ا و إ/1 ميلى (تترا هيدرو وييرانيل بنزيل آدنين) با غلظتهاى (صفر،

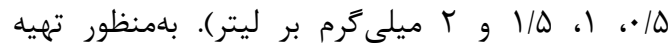
محلولهاى هورمونى موردنظر، مقدار مشخص از هر هورمون بهدقت با ترازو وزن و در نهايت به حجم يك ليتر رسانده شد و با برجسب تفكيك گرديدند. يس از تهيه محلولها، در هر تكرار از تيمار، · ·. داخل هر يترى ديش شسته شده با هييوكلريت سديم

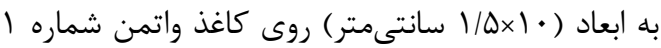
قرار گرفته و به هر يترىديش آب مقطر يا محلول موردنظر (در مجموع · ا ميلىليتر) بسته به نوع تيمار افزوده شد. بلممنظور كاهش ميزان تبخير آب دور

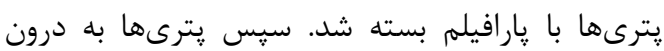

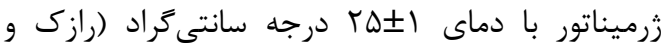

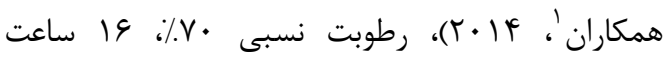

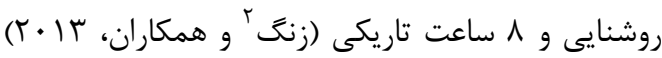
منتقل شدند. شمارش روزانه بذرهاى جوانهزده از روز

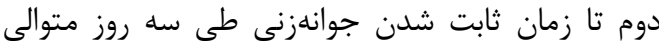
بلهورت روزانه در ساعتى معين انجام و به هن هنام شمارش، بذرهايى جوانهزده تلقى شدند كه طول رول

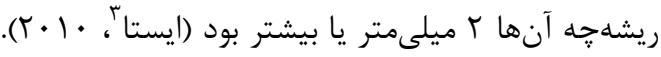

\footnotetext{
${ }^{1}$ Razak

${ }^{2}$ Zeng

${ }^{3}$ ISTA
} 
نشان داد كه تيمار داراى غلظت بالاى سيتوكينين (لهإ ميلى

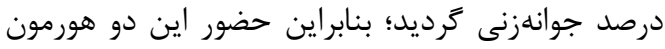

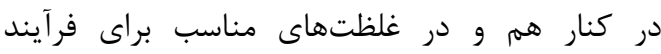

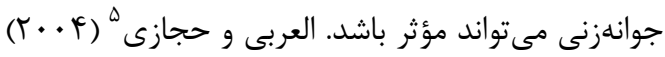

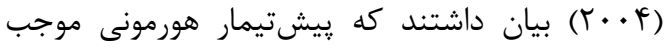

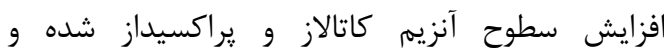
شاخصهاى جوانهزنى را افزايش مىدهد. بر اين اساس

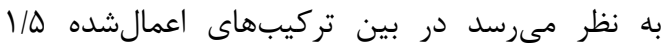

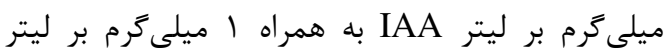
براى به حداكثر رسيدن يويايى اندوختههاى

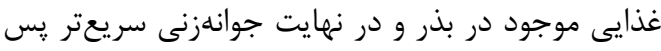

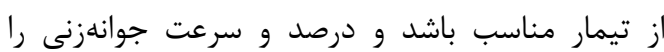
بهبود بخشد.

\section{طول ريشهجه و ساقهجه}

نتايج تجزيه واريانس دادهها نشان داد كه اثر اكسين وسنه

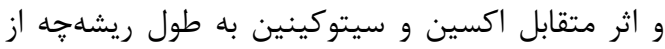

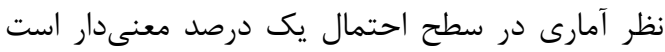

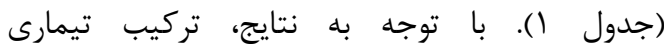

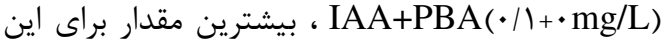

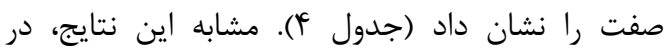

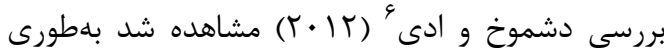

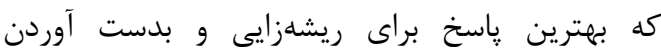
بالاترين طول ريشهجه در محيط كشت موراشيك و

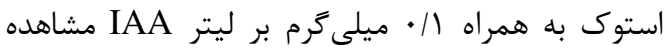
شد. در آزمايشى كه روى ريزازديادى كليماتيس انجام شد با افزايش سطوح (Clematis orientalis L.)

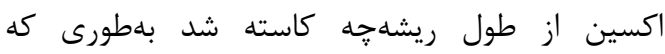
بيشترين طول ريشه جه در \&/ • ميلى گرم بر ليتر اكسين

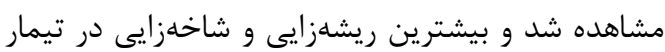
شاهد مشاهده ترديد (ايزدى صادقآبادى و همكاران،

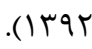

نتايج جدول f ا نشان داد كه بين اين صفت با طول كياهجه

$$
\text { همبستخى معنى دارى وجود دارد. }
$$

\footnotetext{
${ }^{5}$ El-Araby and Hegazi
}

${ }^{6}$ Deshmukh and Ade
• ^ درصد ساييده شد. يس از ها دقيقه سانترفيوز در دور ... حجم • 1 ميلىليتر رسانده و جذب عصاره حاصل در

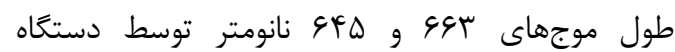
اسيكتروفتومتر قرائت گرديد و در روابط زير جهت

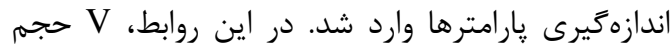

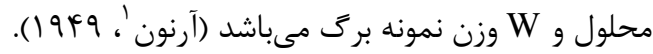

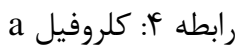
$\mathrm{Ch}_{\mathrm{a}}=12.7$ (A663) - 2.69 (A645) × V/1000W رابطه ه: كلروفيل $\mathrm{Ch}_{\mathrm{b}}=22.9(\mathrm{~A} 645)$ - $2.69(\mathrm{~A} 663) \times \mathrm{V} / 1000 \mathrm{~W}$ رابطه \&: كلروفيل كل $\mathrm{Ch}_{\mathrm{T}}=20.2(\mathrm{~A} 645)+8.02(\mathrm{~A} 663) \times \mathrm{V} / 1000 \mathrm{~W}$ تجزيه دادهاى حاصل توسط نرمافزار MSTAT-C و

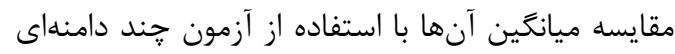
دانكن در سطح احتمال ه درصد انجام گرفت.

\section{نتايج و بحث}

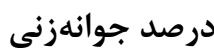

نتايج تجزيه واريانس صفات (جدول () نشان داد كه

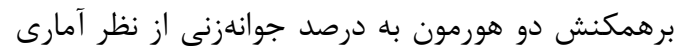

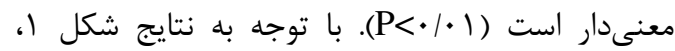

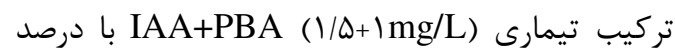
جوانهزنى 94949 بيشترين درصد جوانهزنى را نشان داد.

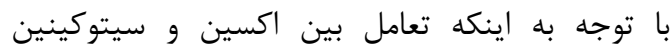

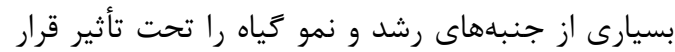

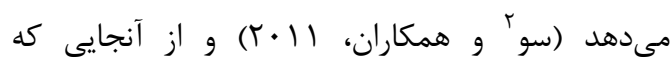

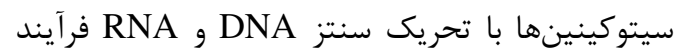

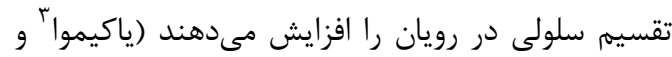

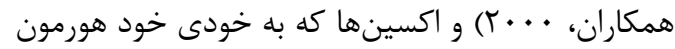

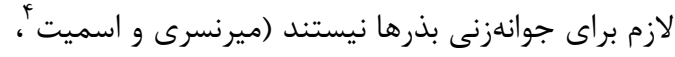

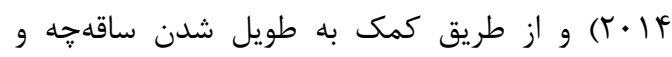
ريشهجه (در كندميان) و نيز با فعال نمودن زمينكرايى

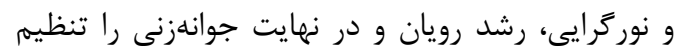

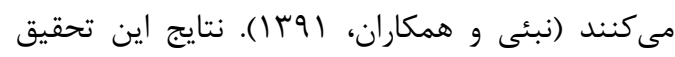

\footnotetext{
${ }^{1}$ Arnon

${ }^{2} \mathrm{Su}$

${ }^{3}$ Yakimova

${ }^{4}$ Miransari and Smith
} 
مجله يثوهش هاى بذر ايران/ سال سوم/ شماره دوم/ هوسا

جدول ا- تجزيه واريانس اثر سطوح مختلف هورمون اكسين و سيتوكينين بر صفات جوانهزنى بذر استويا

\begin{tabular}{|c|c|c|c|c|c|c|c|}
\hline \multicolumn{6}{|c|}{ ميانگين مربعات } & \multirow{2}{*}{ درجه آزادى } & \multirow{2}{*}{ منابع تغييرات } \\
\hline ضريب آلومترى & زيست توده & طول تياهجه & طول ريشه ֶه & طول ساقه ֶه & درصد جوانهزنى & & \\
\hline$\cdot / 4 \Lambda^{*}$ & $\cdot / r \Lambda^{\mathrm{ns}}$ & $\cdot / \Gamma \Lambda^{\mathrm{ns}}$ & $\cdot / r \Lambda^{\mathrm{ns}}$ & $\cdot|\pi|^{*}$ & $\Delta \Lambda / \Lambda r^{n s}$ & f & سيتوكينين \\
\hline$\cdot \pi \cdot{ }^{\mathrm{ns}}$ & $\cdot / V \Delta^{*}$ & $|/ \Gamma|^{\text {*** }}$ & $1 / 9^{* * * *}$ & $.1 \cdot 9^{*}$ & $\Delta \Lambda / \Lambda \mu^{n s}$ & r & اكسين \\
\hline$\cdot 191^{\frac{* *}{*}}$ & $1 / \Delta \Lambda^{* * *}$ & $\cdot / V \cdot *$ & $\cdot / V \varphi^{* * *}$ & $\cdot 1 \cdot \Lambda^{\mathrm{ns}}$ & $r \Delta \cdot / \cdot \Lambda^{* * * *}$ & 19 & سيتوكينين × اكسين \\
\hline$\cdot 11$ & $\cdot / r$. & $\cdot / r$ & .119 & $\cdot / \cdot r$ & 1. & $\Delta \cdot$ & خطا \\
\hline $\mid Q / 1$ & $11 / r$ & $I V / T$ & $r m / l$ & $|V /|$ & $r T / \cdot$ & ي بيرات & درصد ضريب تت \\
\hline
\end{tabular}

ادامه جدول 1-

\begin{tabular}{|c|c|c|c|c|c|c|}
\hline \multicolumn{5}{|c|}{ ميانگين مربعات } & \multirow{2}{*}{ درجه آزادى } & \multirow{2}{*}{ منابع تغييرات } \\
\hline كلروفيل كل & كلروفيل b & a كلروفيل a & محتواى آب نسبى & ضريب جوانهزنى & & \\
\hline$\cdot \mid \Delta V^{* * * * *}$ & $\cdot 1 \cdot 4^{* * * *}$ & $\cdot / / q^{* * * * *}$ & 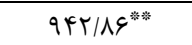 & $F T / F Q^{*}$ & q & سيتوكينين \\
\hline$\cdot \mid f f^{* * * * *}$ & $\cdot / 1 \Lambda^{* * * *}$ & $\cdot / 14^{* * *}$ & $\mid \Lambda T / K \Lambda^{*}$ & $99 / 0 \Lambda^{*}$ & f & اكسين \\
\hline$\cdot / 1 \cdot^{* * * *}$ & $\cdot / \mathcal{F} V^{* * * *}$ & $\cdot \mid \Lambda \Lambda^{* * * *}$ & $q \cdot \mid \lambda v^{\mathrm{ns}}$ & $4 / .^{\mathrm{ns}}$ & 19 & سيتوكينين × اكسين \\
\hline$\cdot 1 \cdot \cdots \wedge$ & $\cdot 1 \cdots \wedge$ & $\cdot 1 \cdots \wedge$ & $91 / 19$ & $9 / \Delta \mu$ & $\Delta \cdot$ & خطا \\
\hline$\mu$ & $9 / 1$ & $F / V$ & TF/G & $1 \cdot / \mu$ & نييرات & درصد : \\
\hline
\end{tabular}

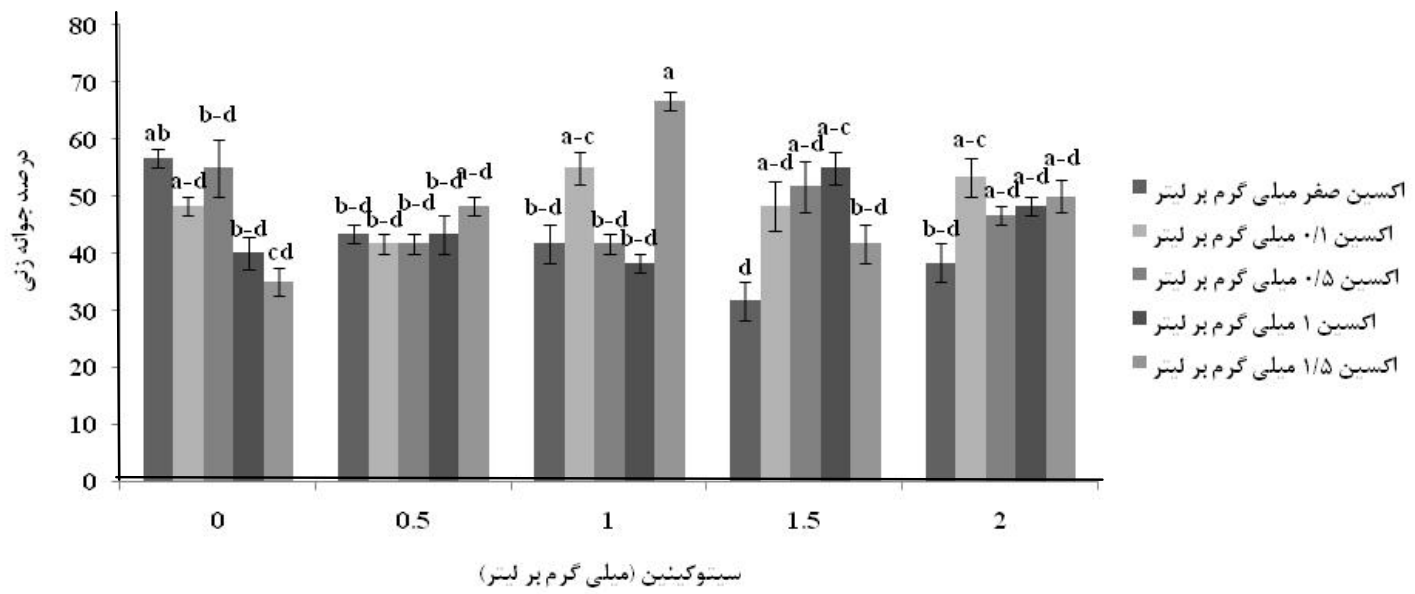

شكل ا- اثر متقابل اكسين و سيتوكينين بر درصد جوانهزنى بذر استويا

بر ليتر اكسين بر صفت طول ساقهجه بيشترين تأثير مثبت را باعث شد اين در حالى است كه بر اساس آزمون دانكن اين سطح از تيمار اكسين تفاوت معنى دارى باس سطوح شاهد و 1/0 ميلى (جدول ץ). در تحقيق ديخرى نيز كه بر روى استويا

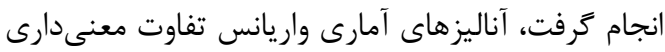

با توجه به جدول ا نتايج نشان داد كه دو هورمون اكسين و سيتوكينين در سطح احتمال ه درصد بر صفت طول ساقه گه معنى دار است. بهطورى كه بيشترين مقدار براى اين صفت با تيمار ه| • ميلى گرم بر ليتر و كمترين

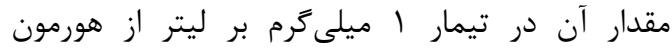
سيتوكينين مشاهده شد (جدول r). تيمار / / • ميلى 
زيست توده

نتايج جدول تجزيه واريانس نشان داد كه اثرات متقابل اكسين و سيتوكينين از نظر آمارى در سطح

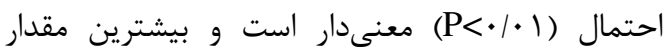

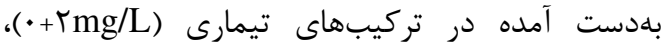
IAA+PBA(•+1// $\mathrm{mg} / \mathrm{L})$ مشاهده شد (س نشان مىدهند كه كمترين غلظت اكسين و دو غلظت بالاى سيتوكينين بيشترين تأثير مثبت را بر افزايش زيستتوده داشتند. از آنجا كه هورمونهاى اكسين و

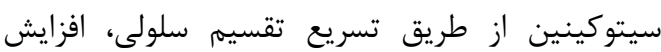
ريشهای جانبى، بخش هوايى و تشكيل بافت آوندى،

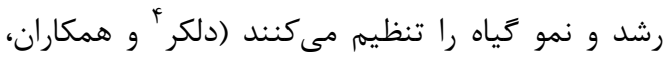

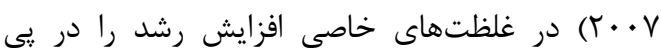
خواهند داشت. همجنين در مشاهدات وميل هُ هو همكاران همكاران (11 • ( )، تيمار • • ميكرومولار IAA و

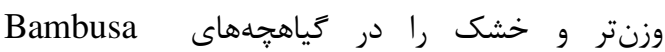
arundinacea و وس/عا Aloe ( كاربرد بنزيل آدنين منجر به افز ايش (vera L. زيستتوده گرديد (حضرتى ياد كورى و طهماسبى

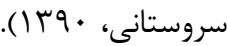

$$
\text { ضريب آلومترى }
$$

نتايج نشان داد كه هورمون سيتوكينين و اثر متقابل اكسين و سيتوكينين به ترتيب در سطح احتمال

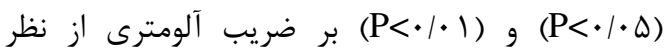

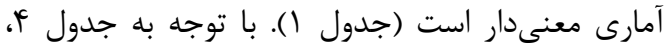

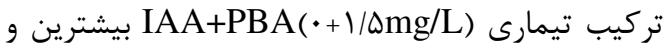
تركيب IAA+PBA(· • • • mg/L) كمترين مقدار براى ضريب آلومترى را نشان داد. در آزمايشى كه توسط

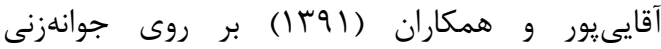
لوبياجيتى انجام شد ضريب آلومترى صفتى بود كه

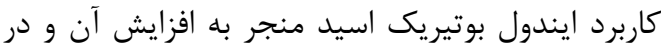
نتيجه كاهش تأثير منفى تنش شورى شد. در كياه

\section{${ }^{4}$ Delker}

${ }^{5}$ Vamil
در ميان تيمارهاى IAA نشان نداد (ابراهيم' وان

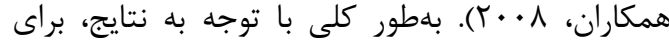
رسيدن به طول ريشهجه و ساقه جه بيشتر، غلظت يايينى از اكسين مىتواند مفيد باشد. همرِنين براى داشتن طول ساقهجه بيشتر غلظتهاى بالاتر از ها • ميلى

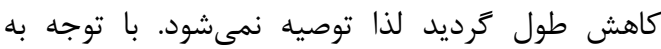
جدول ه همبستگى مثبت و معنىدارى نيز بين طول

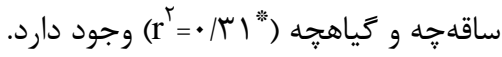

طول گَياهجه

نتايج تجزيه واريانس صفات (جدول ()، نشان داد كه برهمكنش دو هورمون از نظر آمارى بر صفت طول

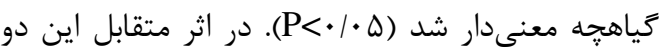

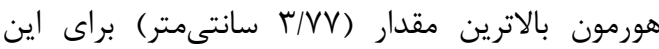
صفت در تركيب تيمارى (AAA+PBA(•/1 • mg/L)

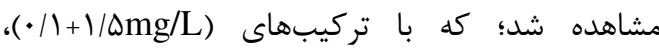

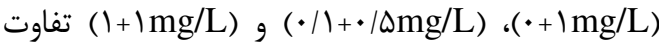

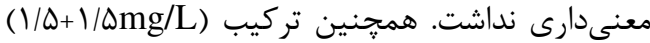
IAA+PBA صفت طول كياهجه را نشان داد كه با تركيبهاى

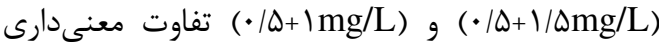

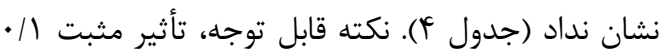
ميلى

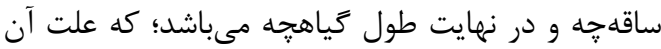
را مىتوان به اثر محرك اكسين در غلظتهاى يايين بر

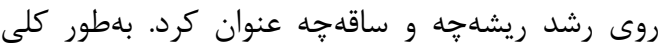
اكسين در تشكيل ريشهجه نقش دارد و سيتوكينين

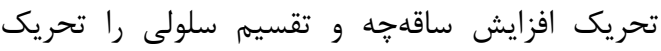

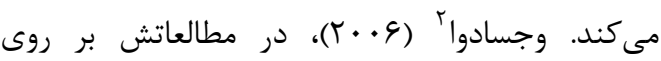

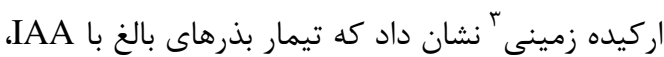
NAA را بهبود مىبخشد. در اين آزمايش مطابق با نتايج جدول

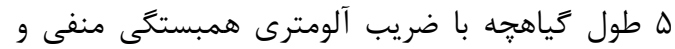
معنى

\footnotetext{
${ }^{1}$ Ibrahim

${ }^{2}$ Vejsadova

${ }^{3}$ Terrestrial Orchids
} 
سرعت و يكنواختى جوانهزنى و توانايى بذر را جهت رويارويى با موانع جوانهزنى افزايش مى دهد.

\section{محتواى آب نسبى برى}

نتايج تجزيه واريانس مشاهدات نشان داد كه تيمار سيتوكينين و اكسين به ترتيب از نظر آمارى در سطح

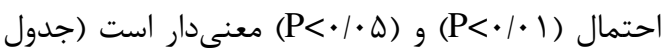
1). شواهد موجود حاكى از آن است كه تيمار بذرها با (آنا ه PBA

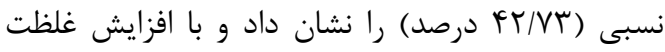

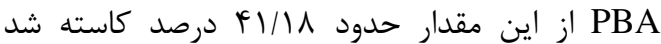

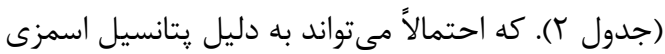

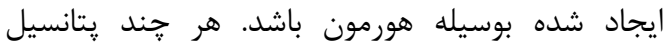
ايجادشده ناجيز باشد. همجنين استفاده از بالاترين

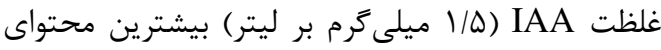
نسبى آب را نشان داد.
استويا با توجه به ارزش اقتصادى اندام هوايى آن، حصول ضريب آلومترى بالا مىتواند مورد توجه قرار كيرد.

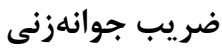
نتايج جدول تجزيه واريانس (جدول () نشان داد كه هورمون اكسين و سيتوكينين براى ضريب جوانهزنى از (جدان نظر آمارى در سطح احتمال (ه (ه)

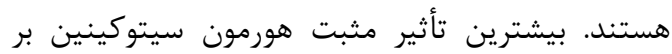
روى اين صفت در عدم استفاده از اين هورمون به دست

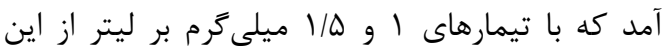

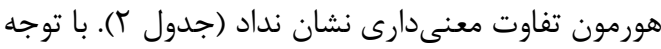
به شكل r، كاربرد هورمون اكسين بر روى اين صفت از از سطح شاهد تا سطح ه/ 1/ ميلى

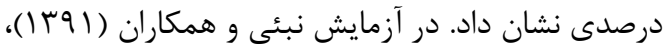
بيشترين درصد و سرعت جوانهزنى در سطح ل.1 يىيى كي براى دو هورمون اكسين و كينتين بهدست آمد.

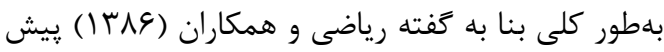
تيمار كردن منجر به يكسرى تغييرات در بذرهاى

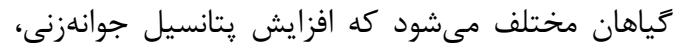

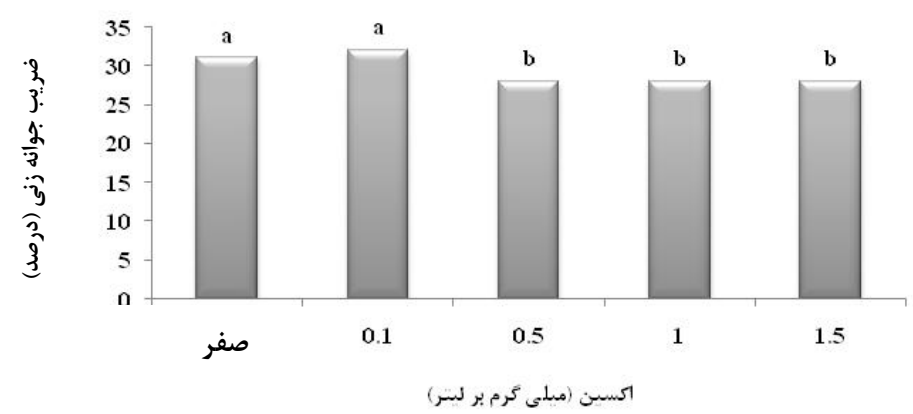

شكل r- مقايسه اثر اكسين بر ميانگين ضريب جوانهزنى بذر استويا، حروف مشابه بر اساس آزمون گند دامنهاى دانكن و در سطح احتمال ه درصد داراى اختلاف معنى دار نيستند.

\begin{tabular}{|c|c|c|c|}
\hline محتواى آب نسبى & $\begin{array}{c}\text { ضريب جوانهزنى } \\
\text { (درصد) }\end{array}$ & طول ساقه & غلظت سيتو كينين \\
\hline$r \cdot / r q a$ & rl/fqa & $1 / \cdot r b c$ & . \\
\hline fr/vra & $\mathrm{rV} / \mathrm{s} \cdot \mathrm{c}$ & $1 / r \wedge a$ & $\cdot 10$ \\
\hline rr/grb & $r / / r \cdot a$ & $\cdot / 9 \vee c$ & 1 \\
\hline$r \Delta / I r c$ & $r \cdot / v r a b$ & $1 / .9 b c$ & $1 / 0$ \\
\hline TG/FFC & $r \wedge / \Lambda \cdot b c$ & $1 / 1 / b c$ & $r$ \\
\hline
\end{tabular}

در هر ستون ميانگينهاى داراى حداقل يك حرف مشابه، بر اساس آزمون جند دامنهاى دانكن تفاوت معنى دارى ندارند (ه • (P 
مجله يثوهش هاى بذر ايران/ سال سوم/ شماره دوم/ هوسا

جدول ه- ضرايب همبستگى ساده بين صفات مربوط به جوانهزنى بذر استويا تحت سطوح هورمونى

\begin{tabular}{|c|c|c|c|c|c|c|c|c|}
\hline$\Lambda$ & $v$ & 4 & $\Delta$ & F & r & r & 1 & \\
\hline & & & & & & & 1 & ا-درصد جوانهزنى \\
\hline & & & & & & 1 & $-\cdot \cdot / \cdot v^{\mathrm{ns}}$ & r-طول ريشه \\
\hline & & & & & 1 & $-\cdot / \cdot v^{\mathrm{ns}}$ & $-\cdot / 1 \Delta^{\mathrm{ns}}$ & r-طول ساقه \\
\hline & & & & 1 & $\cdot|\mu|^{* * * * * 3}$ & $\cdot / 9)^{* * *}$ & $\cdot \cdot \cdot 1^{\mathrm{ns}}$ & F-طول كياهجه \\
\hline & & & 1 & $\cdot / \cdot 1^{\mathrm{ns}}$ & $\cdot / .^{\mathrm{ns}}$ & $\cdot / r^{\mathrm{ns}}$ & $-\cdot / / \Delta^{\mathrm{ns}}$ & ه-زيستتوده \\
\hline & & 1 & $\cdot / \cdot \mathrm{r}^{\mathrm{ns}}$ & $-\cdot / q v^{* *}$ & $-\cdot \cdot \cdot \wedge^{\mathrm{ns}}$ & $-\cdot / 4 \Delta^{* * *}$ & $-\cdot / / r^{\mathrm{ns}}$ & ه-ضريب آلومترى \\
\hline & 1 & $\cdot / / \Lambda^{\mathrm{ns}}$ & $\cdot / \cdot r^{\mathrm{ns}}$ & $-\cdot / \mid f^{\mathrm{ns}}$ & $\cdot / \cdot \Delta^{\mathrm{ns}}$ & $-\cdot / / r^{\mathrm{ns}}$ & $-\cdot \cdot \cdot 1^{\mathrm{ns}}$ & a كلروفيل-v \\
\hline 1 & $\cdot 119^{\frac{* 0}{*}}$ & $\cdot / 19^{\mathrm{ns}}$ & $\cdot / 1 \cdot^{\mathrm{ns}}$ & $-\cdot / 19^{\text {ns }}$ & $-\cdot / \cdot r^{\mathrm{ns}}$ & $-\cdot / r \cdot{ }^{\mathrm{ns}}$ & $-\cdot / / v^{\mathrm{ns}}$ & 1-كلروفيل b \\
\hline$\cdot 199^{* * *}$ & $\cdot / 9 V^{* * * 3}$ & $\cdot \pi \cdot{ }^{\mathrm{ns}}$ & $\cdot / \cdot \mathrm{v}^{\mathrm{ns}}$ & $-\cdot / 19^{\text {ns }}$ & $-\cdot / \cdot 1^{\mathrm{ns}}$ & $-\cdot / 19 r^{\mathrm{ns}}$ & $-\cdot / / r^{\mathrm{ns}}$ & 9-كلروفيل كل \\
\hline
\end{tabular}

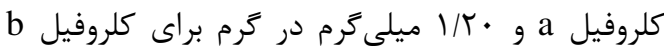

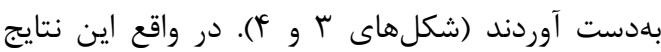
نشان مىدهد كه غلظتهاى بالايى از دو هورمون بلتنهايى توانستهاند تأثير مثبت خود را بر روى روى اين صفت نشان دهند. همجنين تأثير IAA نسبت به راله بر روى اين دو صفت بهتر بوده بهطورى كه IAA در

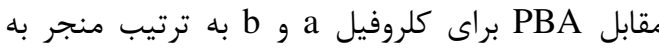

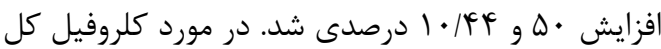
نيز نتايج مشابه حالت قبل است (شكل ه) بهطورى كه كاربرد Img/L PBA و Img/L IAA توانست بيشترين مقدار براى اين دو صفت را ايجاد كند و افزايش كلروفيل كل تحت تيمار IAA در مقايسه با

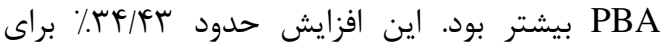

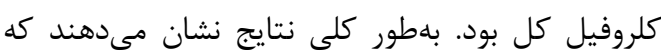
اولاً هورمون اكسين بكار رفته در اين يزوهش نسبت به سيتوكينين توانست مقادير بالاترى از رنخيزهها را ايجاد

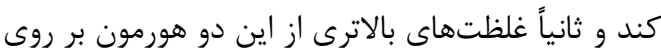
اين صفت مؤثرتر واقع شد.
با اين حال، نتايج تفاوت معنىدارى بين سطوح مختلف

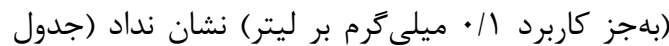
ץ). مىتوان كفت اكسين با تأثير بر جذب مقدار آب در كياه سبب افزايش مقدار RWC مىشود (صالحىفر و

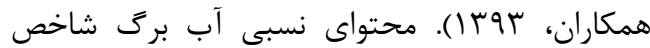
مناسبى براى بيان وضعيت آب در زياهان بوده و وضعيت

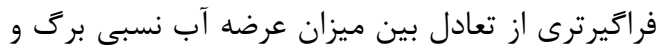

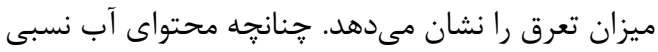
برگ بالا باشد زياه تورم سلولى خود را حفظ كرده و رشد آن تداوم مىيابد (مهدوى و صفرى، ؟وس (I).

\section{رنغَدانه هاى فتوسنتزى}

نتايج جدول تجزيه واريانس (جدول () نشان داد كه اثرات متقابل بين هورمونها از نظر آمارى در سطح

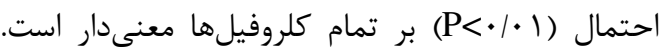

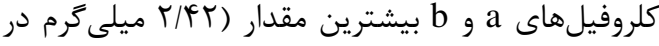

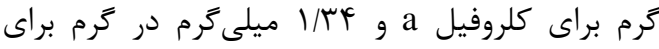

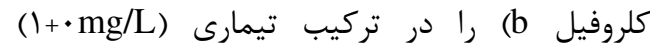
IAA+PBA IAA+PBA 


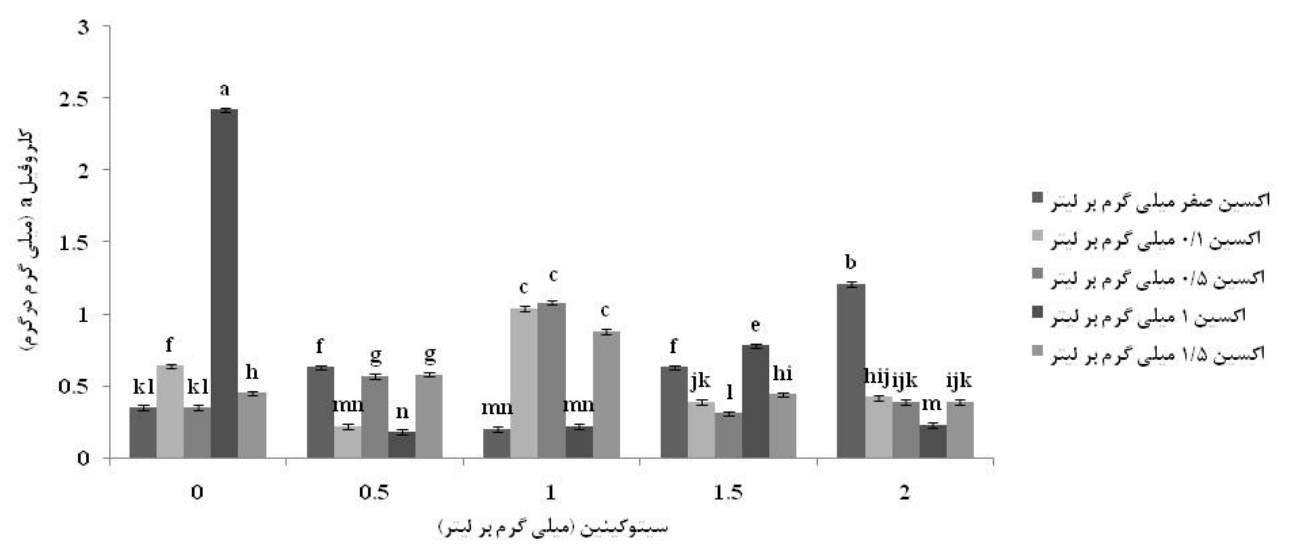

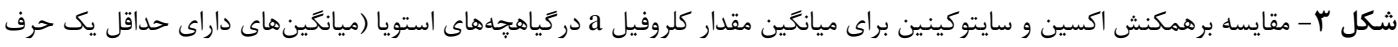

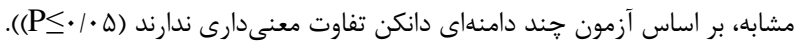

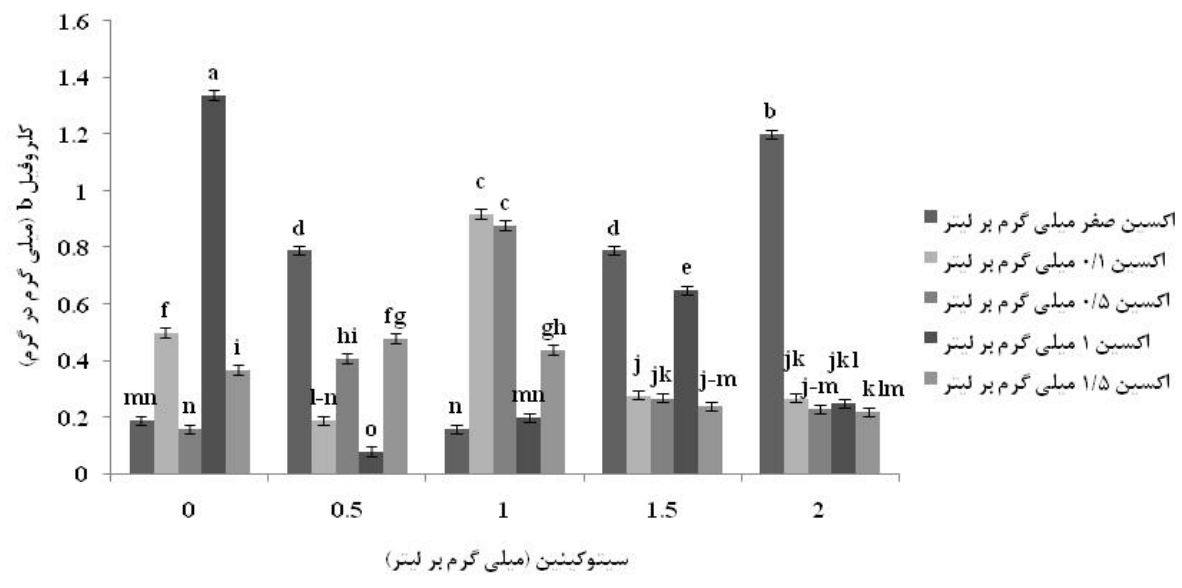

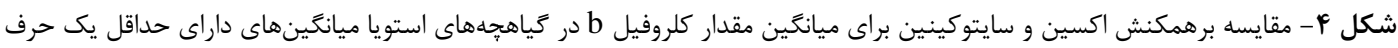

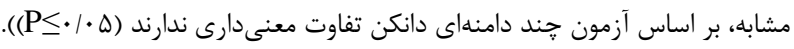

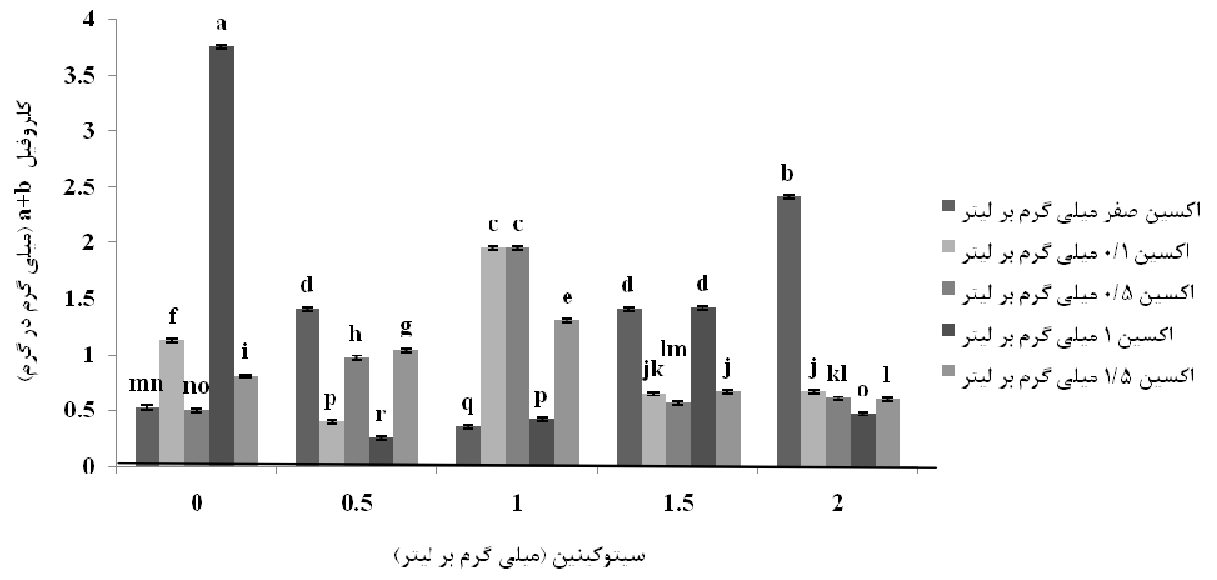

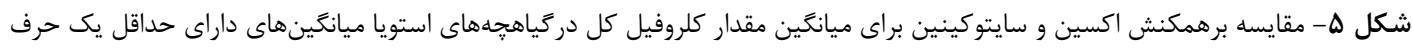

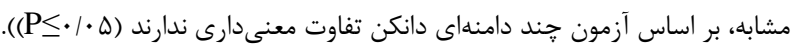


و يويايى آن است و جنانجه در كياه بالا باشد كياه قادر خواهد بود تورم سلولى و در نهايت رشد خود را رانظ حفظ

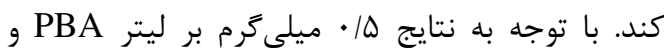

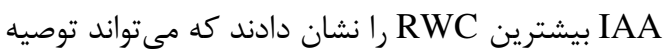

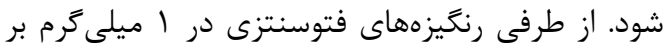
ليتر اكسين بيشترين مقادير را ثبت كردند هر خنديز

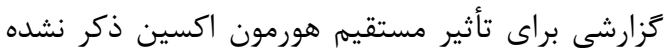
است، اما ممكن است هورمون اكسين بهطور غيرمستقيم

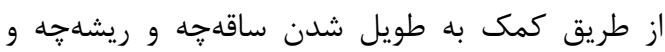
فعال نمودن نوركرايى مثبت و سريعتر ساقهجه و و

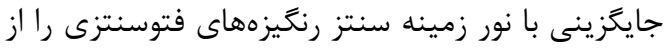

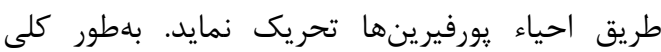

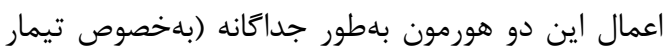
با مؤثرتر واقع شد و توانست نتايج مطلوبترى رئ را ثبت كند.
نتيجه تيرى با توجه به نتايج اين يزوهش، تيمار بذرها با لـئري ميلى

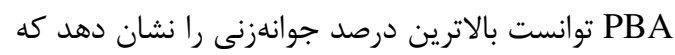

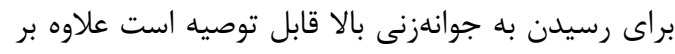

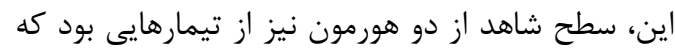

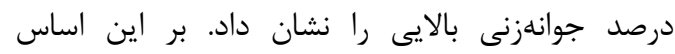

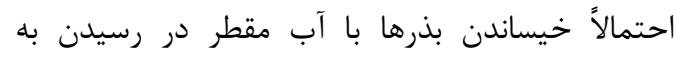

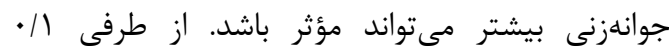

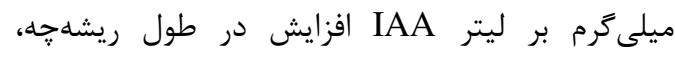

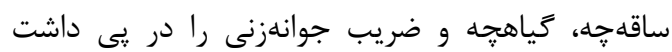
درنتيجه براى رسيدن به حد مطلوبى از اين صفات و و

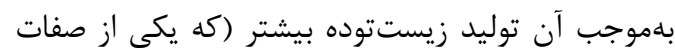

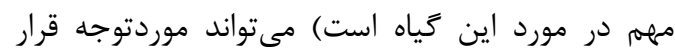

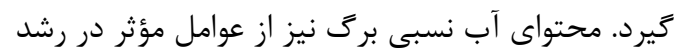

منابع

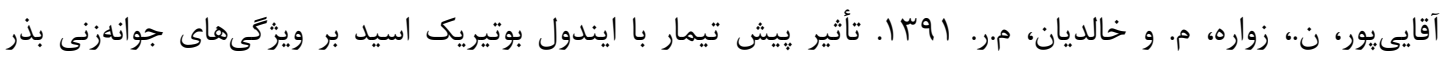

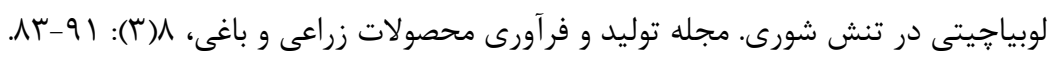

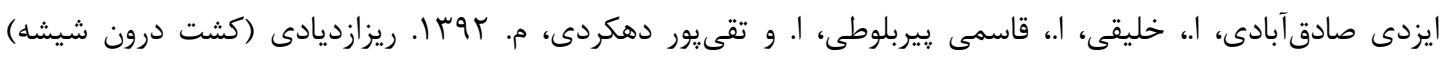

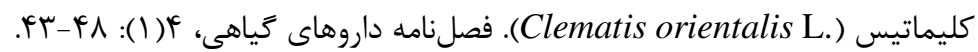

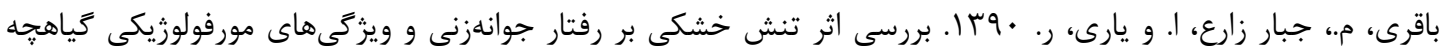

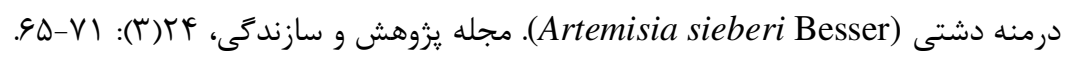

حضرتى ياد كورى، س. و طهماسبى سروستانى، ز.ا. • . 1 ا. بررسى اثر سطوح مختلف كود نيتروزن و محلولياشى هورمون

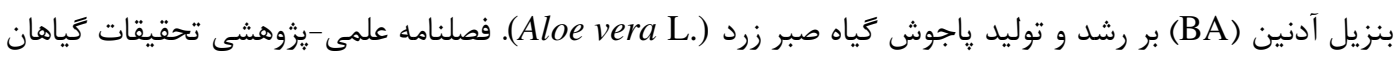

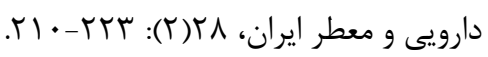

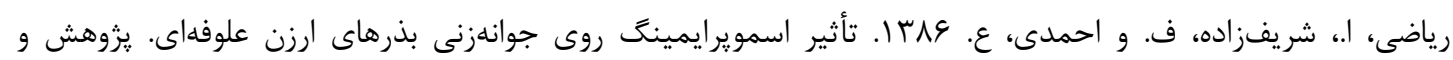
سازند

صالحىفر، م، ربيعى، ب.، افشارمحمديان، م. و اصغرى، ج. بوجا ا. اثر محلولياشى ايندول استيك اسيد و كاينتين بر صفات

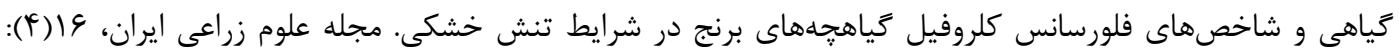

$r q \mu-r \cdot V$

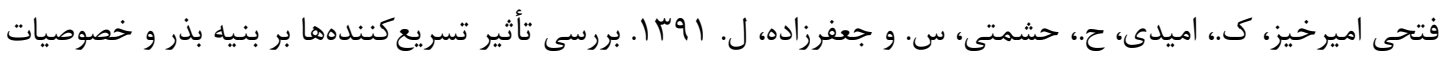

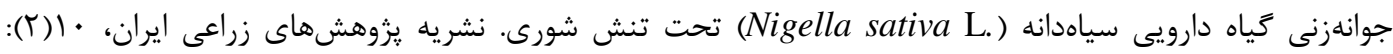
. .

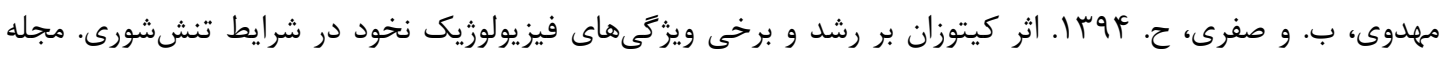

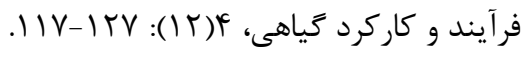




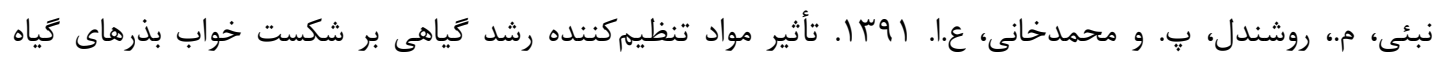

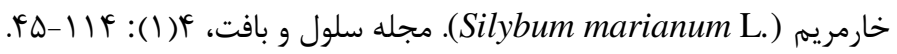

Arnon, D.I. 1949. Copper enzymes in isolated chloroplasts, polyphenoxidase in Beta vulgaris. Plant Physiology, 24(1): 1-15.

Ayub, M., Ibrahim, M., Noorka, I.R., Tahir, M., Tanveer, A., and Ullah, A. 2013. Effect of seed priming on seed germination and seedling growth of garden cress (Lepidium sativum L.). International Journal of Agriculture and Applied Sciences, 5(2): 1-5.

Azizi, P., Rafii, M.Y., Maziah, M., Abdullah, S.N.A., Hanafi, M.M., Latif, M.A., Rashid, A.A., and Sahebi, M. 2015. Understanding the shoot apical meristem regulation: A study of the phytohormones, auxin and cytokinin, in rice. Mechanisms of Development, 135: 1-15.

Delker, C., Zolman, B.K., Miersch, O., and Wasternack, C. 2007. Jasmonate biosynthesis in Arabidopsis thaliana requires peroxisomal $\beta$-oxidation enzymes-Additional proof by properties of pex6 and aim1. Phytochemistry, 68(12): 1642-1650.

Deshmukh, S.H., and Ade, R. 2012. In vitro rapid multiplication of Stevia rebaudiana: an important natural sweetener herb. Bioscience, 4(3): 105-108.

El-Araby, M.M., and Hegazi, A. Z. 2004. Responses of tomato seeds to hydro- and osomo- priming and possible relations of some antioxidant enzyme and endogenous polyamine fractions. Egyptian Journal of Biology, 6(1): 81-93.

Gajdosova, S., Spichal, L., Kaminek, M., Hoyerova, K., Novak, O., Dobrev, P.I., and Motyka, V. 2011. Distribution, biological activities, metabolism, and the conceivable function of cis-zeatintype cytokinins in plants. Journal of Experimental Botany, 62: 2827-2840.

GhorbaniJavid, M., Sorooshzadeh, A., Moradi, F., Sanavy, S.A.M.M., and Allahdadi, I. 2011. The role of phytohormones in alleviating salt stress in crop plants. Australian Journal of Crop Science, 5(6): 726-734.

Ibrahim, I.A., Nasr, M.I., Mohammed, B.R., and El-Zefzafi, M.M. 2008. Plant growth regulators affecting in vitro cultivation of Stevia rebaudiana. Sugar Technology, 10(3): 254-259.

ISTA. 2010. International rules for seed testing. International seed testing association (ISTA). 543: $1-53$.

Karuppusamy, S. 2009. A review on trends in production of secondary metabolites from higher plants by in vitro tissue, organ and cell cultures. Journal of Medicinal Plants, 3(13): 1222-1239.

Kieber, J.J., and Schaller, G.E. 2014. Cytokinins. In the Arabidopsis Book.

Kumar, R., Sharma, S., and Sood, S. 2014. Yield components, light interception and marker compound accumulation of stevia (Stevia rebaudiana Bertoni) affected by planting material and plant density under western Himalayan conditions. Archives of Agronomy and Soil Science, 60(12): 1731-1745.

Miransari, M., and Smith, D.L. 2014. Plant hormones and seed germination. Environmental and Experimental Botany, 99: 110-121.

Pol, J., Ostra, E. V., Karasek, P., Roth, M., Benesova, K., Kotlarlkova, P. and Caslavsky, J. 2007. Comparison of two different solvents employed for pressurised fluid extraction of stevioside from Stevia rebaudiana: methanol versus water. Analytical and Bioanalytical Chemistry, 388(8): 1847-1857.

Qasim, M., Ashraf, M.M., Jamil, A.M., Rehman, Y.S.U., and Rha, E.S. 2003. Water relations and gas exchange properties in some elite canola (Brassica napus L.) lines under salt stress. Annual Application of Biology, 142(3): 307-316. 
Raina, R., Bh, S.K., and Sharma, Y. 2013. Strategies to improve poor seed germination in Stevia rebaudiana, a low calorie sweetener. Journal of Medicinal Plants Research, 7(24): 1793-1799.

Ramesh, K., Singh, V., and Megeji, N.W. 2006. Cultivation of stevia [Stevia rebaudiana (Bertoni)]: A comprehensive review. Advances in Agronomy, 89: 137-177.

Razak, U. N.A.A., Ong, C.B., Yu, T.S., and Lau, L.K. 2014. In vitro micropropagation of Stevia rebaudiana Bertoni in Malaysia. Brazilian Archives of Biology and Technology, 57(1): 23-28.

Reis, M., Coelho, L., Santos, G., Kienle, U., and Beltrão, J. 2015. Yield response of stevia (Stevia rebaudiana Bertoni) to the salinity of irrigation water. Agricultural Water Management, 152: 217-221.

Su, Y.H., Liu, Y.B., and Zhang, X.S. 2011. Auxin-cytokinin interaction regulates meristem development. Molecular Plant, 4(4): 616-625.

Vamil, R., Aniat-ul-haq, R., Agnihotri, K., and Sharma, R. 2011. Effect of certain plant growth regulators on the seedling survival, biomass production and proline content of Bambusa arundinacea. Science Research Reporter, 1(2): 44-48.

Vanneste, S., and Friml, J. 2009. Auxin: a trigger for change in plant development. Cell, 136(6): 1005-1016.

Vejsadova, H. 2006. Factors affecting seed germination and seedling growth of Terrestrial Orchids cultured in vitro. Acta Biologica Cracoviensia Series Botanica, 48: 109-113.

Woodward, A.W., and Bartel, B. 2005. Auxin: regulation, action, and interaction. Annals of Botany, 95(5): 707-735.

Yakimova, E., Kapchina, V., Groshkoff, I., and Ivanova, G. 2000. Effects of BA and CPPU on protease and $\alpha$-amylase activity of in vitro cultured explants of Rosa hybrida L. Bulgarian Journal of Plant Physiology, 26(1-2): 39-47.

Zeng, J., Chen, A., Li, D., Yi, B., and Wu, W. 2013. Effects of salt stress on the growth, physiological responses, and glycoside contents of Stevia rebaudiana Bertoni. Journal of Agricultural and Food Chemistry, 61(24): 5720-5726.

Zhao, Y. 2010. Auxin biosynthesis and its role in plant development. Annual Review of Plant Biology, 61: 49-64. 


\title{
The Effect of Auxin and Cytokinin on Some Morpho-Physiological and Germination Characteristics of Stevia (Stevia rebaudiana Bertoni) Seeds
}

\author{
Razieh Sarami $^{1}$, Heshmat Omidi ${ }^{2, *}$, Abdolamir Bostani ${ }^{3}$ \\ ${ }^{1}$ M.Sc. Seed Science and Technology, Department of Agronomy, Shahed University Tehran, \\ Tehran, Iran \\ ${ }^{2}$ Assistant Professor, Agricultural College and Medicinal Plant Research Center, Shahed \\ University Tehran, Tehran, Iran \\ ${ }^{3}$ Department of Soil Sciences, Faculty of Agriculture Science, Shahed University Tehran, Tehran, \\ Iran \\ *Corresponding author, E-mail address: omidi@shahed.ac.ir
}

(Received: 17.01.2016 ; Accepted: 26.06.2016)

\begin{abstract}
The present study was conducted to investigate the efficiency of hormonal pretreatment on increasing germination and early growth of seedling in the Seed Technology Laboratory of Shahed University in 2015 as a factorial experiment, adopting a completely randomized design with 4 replications. The treatments were: 5 levels of IAA (indole-3-acetic acid) namely, zero, 0.1, 0.5, 1 and $1.5 \mathrm{mg} / \mathrm{L}$ and 5 levels of PBA (Tetra hydro pyranyl benzyl adenine), which were zero, $0.5,1$, 1.5 and $2 \mathrm{mg} / \mathrm{L}$. Analysis of variance showed that the use of the two hormones and their interactions had a significant effect on all traits such as seed germination, biomass, leaf relative water content and photosynthetic pigments. The highest percentage of germination $(66.66 \%)$ was obtained in $1.5 \mathrm{mg} / \mathrm{L}$ IAA with $1 \mathrm{mg} / \mathrm{L}$ PBA. $0.5 \mathrm{mg} / \mathrm{L}$ PBA and in $0.1 \mathrm{mg} / \mathrm{L} \mathrm{IAA}$ the longest shoot (1.28 and $1.17 \mathrm{~cm}$, respectively) was obtained. Germination coefficient decreased by about $12.5 \%$ by increasing IAA from 0.1 to $1.5 \mathrm{mg} / \mathrm{L}$. The greatest relative water content $(42.73 \%$ and $37.38 \%)$ was obtained with $0.5 \mathrm{mg} / \mathrm{L} \mathrm{PBA}$ and $1.5 \mathrm{mg} / \mathrm{L}$ IAA, respectively. Combination of IAA+PBA $(0.1+0 \mathrm{mg} / \mathrm{L})$ had a positive effect on both the length of the root and seedling. The high concentration of PBA and the lowest amount of IAA had similar results in terms of plant biomass. The highest plant biomass $(4.33 \mathrm{mg})$ was obtained in seeds treated with $2 \mathrm{mg} / \mathrm{L}$ of cytikinin and 0.1 $\mathrm{mg} / \mathrm{L}$ of auxin. Photosynthetic pigments were also affected by these two hormones though the IAA was more effective than PBA. The finding was that auxin and cytokinin increase germination and improve the morpho-physiological indicators and thus increase the yield of Stevia.
\end{abstract}

Keywords: Indole-3-acetic acid, Tetra hydro pyranyl benzyl adenine, Germination coefficient, Biomass 